\title{
Structural and magnetic properties of cobalt- doped iron oxide nanoparticles prepared by solution combustion method for biomedical applications
}

\author{
This article was published in the following Dove Press journal: \\ International Journal of Nanomedicine \\ I October 2015 \\ Number of times this article has been viewed
}

\author{
Kaliyamoorthy Venkatesan' \\ Dhanakotti Rajan Babu' \\ Mane Prabhu Kavya Bai \\ Ravi Supriya ${ }^{2}$ \\ Radhakrishnan Vidya ${ }^{2}$ \\ Saminathan Madeswaran' \\ Pandurangan Anandan ${ }^{3}$ \\ Mukannan Arivanandhan ${ }^{3}$ \\ Yasuhiro Hayakawa ${ }^{3}$ \\ 'School of Advanced Sciences, ${ }^{2}$ School \\ of Bio Sciences and Technology, VIT \\ University, Vellore, Tamil Nadu, India; \\ ${ }^{3}$ Research Institute of Electronics, \\ Shizuoka University, Hamamatsu, Japan
}

\begin{abstract}
Cobalt-doped iron oxide nanoparticles were prepared by solution combustion technique. The structural and magnetic properties of the prepared samples were also investigated. The average crystallite size of cobalt ferrite $\left(\mathrm{CoFe}_{2} \mathrm{O}_{4}\right)$ magnetic nanoparticle was calculated using Scherrer equation, and it was found to be $16 \pm 5 \mathrm{~nm}$. The particle size was measured by transmission electron microscope. This value was found to match with the crystallite size calculated by Scherrer equation corresponding to the prominent intensity peak (311) of X-ray diffraction. The high-resolution transmission electron microscope image shows clear lattice fringes and high crystallinity of cobalt ferrite magnetic nanoparticles. The synthesized magnetic nanoparticles exhibited the saturation magnetization value of $47 \mathrm{emu} / \mathrm{g}$ and coercivity of 947 Oe. The anti-microbial activity of cobalt ferrite nanoparticles showed better results as an anti-bacterial agent. The affinity constant was determined for the nanoparticles, and the cytotoxicity studies were conducted for the cobalt ferrite nanoparticles at different concentrations and the results are discussed.
\end{abstract}

Keywords: cytotoxicity, HR-TEM, magnetic nanoparticles, VSM

\section{Introduction}

The ferromagnetic and semiconducting properties of spinel ferrites causes them to be considered as magnetic semiconductors. ${ }^{1}$ Due to their extraordinary electric and magnetic properties, nanosized ferrites are used in varies applications in different areas like ferrofluids, ${ }^{2,3}$ magnetic drug delivery, ${ }^{4,5}$ high-density information storage ${ }^{6}$ photocatalysis, ${ }^{7,8}$ and gas sensors. ${ }^{9-11}$ Among the various ferrites, cobalt ferrites have received recent attention because they possess excellent chemical stability, good mechanical hardness, remarkably high electrical resistivity, and large permeability at high frequency in addition to being cost effective. ${ }^{12,13}$

Magnetocrystalline anisotropy depends upon their L-S coupling which is present in the crystal lattices. The magnetocrystalline anisotropy of cobalt ferrite is contributed by $\mathrm{Fe}^{3+}$ and $\mathrm{Co}^{2+}$ ions. The $\mathrm{Co}^{2+}$ cations on the $\mathrm{B}$ site of the spinel consist of seven $\mathrm{d}$ electrons, three of them being unpaired, and they have high spin ligand fields. This helps them to contribute to the magnetocrystalline anisotropy better than $\mathrm{Fe}^{3+}$ cations, even though the coupling depends on the site. It is to be considered that the A site occupies the tetrahedral symmetry and the B site occupies the octahedral symmetry. ${ }^{14}$ The spinel structure is a face-centered cubic arrangement of 32 oxygen ions in the unit cell. The oxygen ions have 32 octahedral (B) sites and 64 tetrahedral (A) sites. ${ }^{15}$
Correspondence: Dhanakotti Rajan Babu Advanced Materials Research Centre, School of Advanced Sciences, VIT University, Vellore, Tamil Nadu 6320I4, India

Email drajanbabu@vit.ac.in
International Journal of Nanomedicine 2015:10 (Suppl I:Challenges in biomaterials research) 189-198 I 89 (c) (1) (2) ๑ 2015 Venkatesan et al. This work is published by Dove Medical Press Limited, and licensed under Creative Commons Attribution - Non Commercial (unported, 33.0) permission from Dove Medical Press Limited, provided the work is properly attributeded. Permisisions beyond the scope of the license are administered by Dove Medical Press Limited. Information on permisision from Dove Medical Press Limited, provided the work is properly attributed. Pe
how to request permission may be found at: http://www.dovepress. com/permissions.php 
Some of the different ways of preparing the nanoparticles using bottom-up synthesis are: coprecipitation, ${ }^{16}$ microemulsion method, ${ }^{17}$ spray pyrolysis, ${ }^{18}$ hydrothermal synthesis, ${ }^{19}$ precursor, ${ }^{20}$ sol-gel method, ${ }^{21}$ and self-propagated or selfcombustion method (also known as solution combustion method). ${ }^{22}$ Among these methods, combustion method is one of the facile and single-step processes employed in the preparation of nanoparticles. Using this method, we can get single phase without further calcination steps, and the metal ions are uniformly distributed. The glycine (as a fuel)-to-metal nitrate ratio also plays a major role in the combustion synthesis. In this paper, we report the synthesis of $\mathrm{CoFe}_{2} \mathrm{O}_{4}$ using combustion route at lower processing temperature and also the anti-microbial activity of cobalt ferrite nanoparticles.

\section{Experiment}

\section{Sample preparation}

Analytical grade iron nitrate $\left(\mathrm{Fe}\left(\mathrm{NO}_{3}\right)_{3} \cdot 9 \mathrm{H}_{2} \mathrm{O}\right)$ and cobalt nitrate $\left(\mathrm{Co}\left(\mathrm{NO}_{3}\right)_{2} \cdot 6 \mathrm{H}_{2} \mathrm{O}\right)$ were used as oxidizers, and glycine $\left(\mathrm{NH}_{2} \mathrm{CH}_{2} \mathrm{COOH}\right)$ was used as a fuel for the combustion reaction. Fuels are complexant agents in which the metal ions facilitate homogeneous mixing of cations in the precursor solutions. Various stoichiometric ratios such as fuel lean $(\varphi<1)$, stoichiometry $(\varphi=1)$, and rich $(\varphi>1)$ were chosen as the conditions for optimization to control the combustion synthesis, where $\varphi$ is the multiplication factor in the order of the stoichiometric ratio. Cobalt nitrate, iron nitrate, and glycine were used as precursors. According to propellant chemistry, the total valances of the precursors (oxidizing and reducing agents) were $-10,-15$, and +9 . The required stoichiometric ratio to ignite the solution is $-40+9 n=0$, ie, $\mathrm{n}=4.44 \mathrm{~mol}$ of glycine. To prepare $\mathrm{CoFe}_{2} \mathrm{O}_{4}$, the oxidizers and the fuel were taken in molar proportion of 2.91:8.08:3.33 g/mol. The different ratios of the fuel are tabulated in Table 1.The metal nitrates and the fuel were dissolved in deionized water, and the mixture was stirred for an hour to obtain a clear homogeneous solution. The homogeneous solution was then placed in the preheated furnace, and the ignition was initiated. After the combustion reaction, soft, fluffy foam, black in color, was obtained (Figure 1). This was easily ground by mortar and pestle to make a fine powder, and the sample was subjected to different characterizations.

\section{Antimicrobial assay}

The antimicrobial activity was tested against Microbial Type Culture Collection (MTCC) such as Escherichia coli (MTCC 1701), Acetobacter nitrogenifigens (MTCC 6912), and Pseudomonas fluorescens (MTCC 7096), which were collected from Imtech, Chandigarh, India.

Dimethyl sulfoxide was used as a solvent to prepare the colloidal solution of cobalt ferrite nanoparticle at different concentrations of 50,100, and $200 \mathrm{mg} / \mathrm{L}$. Antibacterial activity was evaluated to determine the minimum inhibitory concentration (MIC) of the cobalt ferrite nanoparticle inhibiting the growth of bacteria.

\section{Testing for antibacterial activity}

The pure cultures were transferred to sterile tryptone broth, which was then incubated overnight at $37^{\circ} \mathrm{C}$. The broth culture was used for further determination of MIC. The cultures were swabbed on the sterile Müller Hinton agar plates with four wells made of sterile cork borer. Each well was loaded with $20 \mu \mathrm{L}$ of the cobalt ferrite nanoparticle solution. The plates were incubated to observe the clear zone of inhibition around the wells. The zone of inhibition for bacterial cultures was measured using the formula given below: ${ }^{23}$

$\begin{gathered}\text { Zone of } \\ \text { inhibition }\end{gathered}=\frac{\text { Zone of diameter in } \mathrm{mm}-\text { Well diameter in } \mathrm{mm}}{2}(1)$

\section{Cytotoxicity assay}

The MCF-7 cells were plated separately in 96-well plates at a concentration of $1 \times 10^{5}$ cells/well. After 24 hours, cells were washed twice with $100 \mu \mathrm{L}$ of serum-free medium and starved for an hour at $37^{\circ} \mathrm{C}$. After starvation, cells were treated with different concentrations of test compound $(75-1,000 \mu \mathrm{g} / \mathrm{mL})$ for 24 hours. At the end of the treatment period the medium was aspirated and serum-free medium containing 3-(4,5dimethylthiazol-2-yl)-2,5-diphenyltetrazolium bromide (MTT) $(0.5 \mathrm{mg} / \mathrm{mL})$ was added and incubated for 4 hours at $37^{\circ} \mathrm{C}$ in a $\mathrm{CO}_{2}$ incubator. The $50 \%$ inhibitory concentration

Table I Structural parameters of $\mathrm{CoFe}_{2} \mathrm{O}_{4}$

\begin{tabular}{llllll}
\hline $\begin{array}{l}\text { Prepared } \\
\text { conditions }\end{array}$ & $\begin{array}{l}\text { Oxidant/fuel } \\
\text { ratio }\end{array}$ & $\begin{array}{l}\text { Crystallite } \\
\text { size }(\mathbf{n m})\end{array}$ & $\begin{array}{l}\text { Lattice constant } \\
(\mathbf{n m})\end{array}$ & ${\text { Volume }(\mathbf{n m})^{3}}$ & ${\text { Density }\left(\mathbf{g} / \mathbf{c m}^{3}\right)}^{3}$ \\
\hline A (Fuel lean) & $\mathrm{I}: 2: 2.22$ & $16 \pm 5$ & 0.83 & 0.58 & 5.40 \\
B (Stoichiometry) & $\mathrm{I}: 2: 4.44$ & $38 \pm 5$ & 0.84 & 0.60 & 5.19 \\
C (Fuel rich) & $\mathrm{I}: 2: 8.88$ & $55 \pm 5$ & 0.84 & 0.59 & 5.21 \\
\hline
\end{tabular}



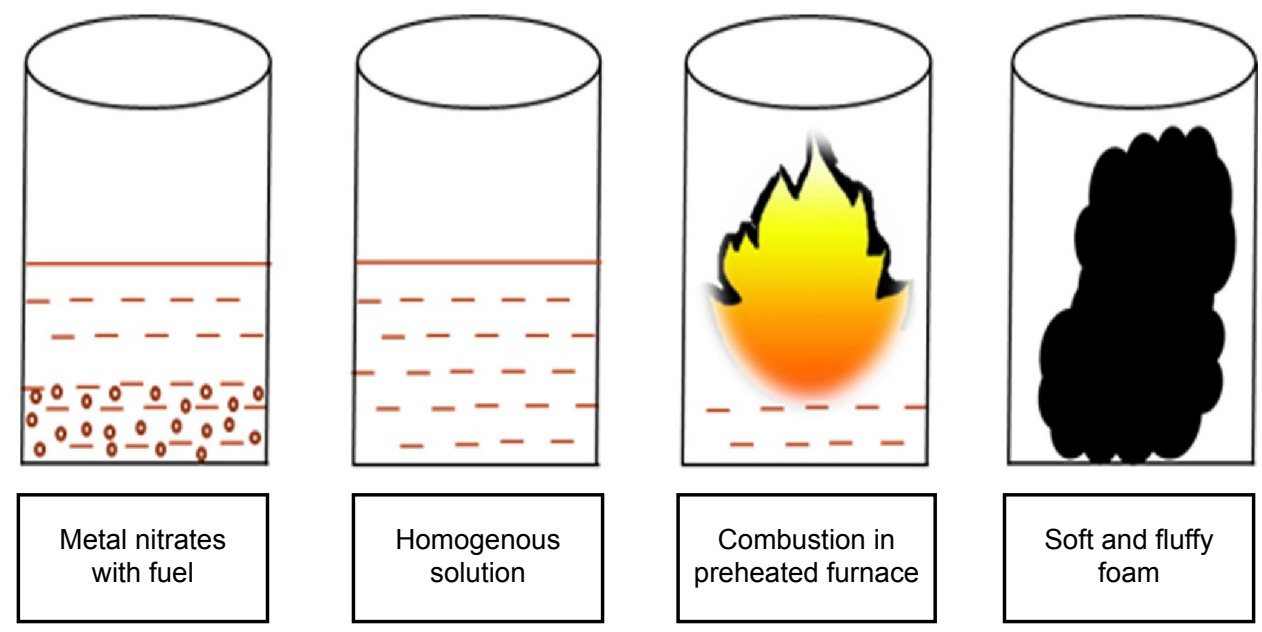

Figure I Preparation model of cobalt ferrite magnetic nanoparticles using combustion reaction.

value of the crude extracts was identified for normal fibroblast cell line.

The MTT-containing medium was then discarded and the cells were washed with phosphate-buffered saline $(200 \mu \mathrm{L})$. The crystals were then dissolved by adding $100 \mu \mathrm{L}$ of dimethyl sulfoxide and this was mixed properly by pipetting up and down. Spectrophotometrical absorbance of the purpleblue formazan dye was measured in a microplate reader at $570 \mathrm{~nm}$ (Bio-Rad 680). Cytotoxicity was determined using GraphPad Prism 5 software.

\section{Characterizations}

Powder X-ray diffraction analysis was done by Bruker D8 ADVANCE (Bruker AXS GmbH, Karlsruhe, Germany) with $\mathrm{CuK} \alpha_{1}$ radiation $(\lambda=1.54 \AA$ ). Shimadzu (Shimadzu Scientific Instruments Inc., Columbia, MD, USA) model IR Affinity Fourier-transform infrared (FT-IR) spectroscopy was used for identifying the functional groups of $\mathrm{CoFe}_{2} \mathrm{O}_{4}$. The surface morphology and elemental analysis were carried out using fieldemission scanning electron microscope (FEI Quanta FEG 200) and SEM with energy dispersive X-ray spectroscopy (EDX) (INCA; Oxford Instruments, Abingdon, UK). The cobalt ferrite nanoparticles were taken to high-resolution (HR) transmission electron microscope (TEM) (JEM-2100F), and the particle size and lattice fringes were analyzed. The magnetic measurements (M-H curve) were carried out at room temperature with the help of vibrating sample magnetometer (VSM) (Model 7410; Lake Shore Cryotronics Inc., Westerville, OH, USA).

\section{Results and discussion Powder X-ray diffraction}

The crystalline nature of the prepared cobalt ferrite was analyzed by powder X-ray diffraction. The average crystallite size was calculated using the Scherrer equation, and was found to be $16 \pm 5 \mathrm{~nm}$ :

$$
D=\frac{k \lambda}{\beta \cos \theta}
$$

where $D$ is crystallite size, $\mathrm{k}$ is the shape factor, $\lambda$ is the wavelength of the radiation, $\beta$ is the full width at half maximum of the diffraction peak, and $\theta$ is the corresponding diffraction angle. Cobalt metal was indexed to face center cubic structure with space group of Fm $\overline{3} \mathrm{~m}$ (Joint Committee on Powder Diffraction Standards [JCPDS] data card number \#15-0806) and iron metal was indexed to body center cubic structure with space group of Im $\overline{3} \mathrm{~m}$ (JCPDS data card number \#06-0696). ${ }^{24}$ The entire observed X-ray diffraction pattern matched the JCPDS data (card number \#022-1086) of $\mathrm{CoFe}_{2} \mathrm{O}_{4}$ along with the space group of $\mathrm{Fd} \overline{3} \mathrm{~m}$.

From the X-ray diffraction analysis, the sample which was prepared in confirmation with stoichiometric ratios (fuel to oxidizer) exhibited good crystalline nature (Figure 2). In fuel lean condition, the final adiabatic temperature was controlled, so that the end product crystallized with smaller size was comparable with that of other conditions. The X-ray diffraction peaks of the sample prepared at fuel lean showed a much broader full width at half maximum owing to less adiabatic temperature. By changing the stoichiometric ratios, the adiabatic temperature was controlled in the combustion reaction. The reasons for the result could be as follows: a combustion reaction is influenced by the type of fuel and also the fuel to oxidizer ratio. The exothermic temperature of the redox reaction $\left(T_{\mathrm{ad}}\right)$ varies from $1,000^{\circ} \mathrm{C}$ to $1,500^{\circ} \mathrm{C}$ in short duration. When the precursor solution was placed into the preheated furnace, the solution ignited with $\mathrm{NO}_{\mathrm{X}}$ and due to decomposition, combustible gases like $\mathrm{HNCO}$ and $\mathrm{NH}_{3}$ were produced. ${ }^{25}$ 


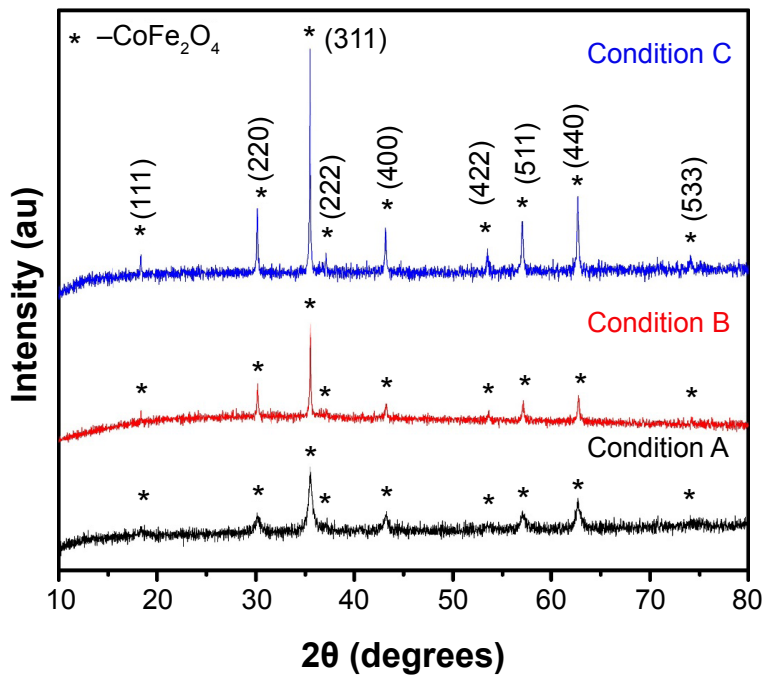

Figure 2 Powder $X$-ray diffraction pattern of cobalt ferrite magnetic nanoparticles. Notes: Condition A, oxidant to fuel ratio is lean; Condition B, oxidant to fuel ratio is stoichiometry; Condition $\mathrm{C}$, oxidant to fuel ratio is rich. *Indicates the single phase of $\mathrm{CoFe}_{2} \mathrm{O}_{4}$.

The nonstoichiometry condition between metal nitrates and complexant valences was preferred for controlling the adiabatic temperature in the combustion reaction. Adjustment of the complexant-to-metal nitrate ratio allowed the control of flame and time in addition to influence its effect on the phase formation, growth of the particle size, shape, and their agglomeration states. ${ }^{15}$ Combustion reaction route increases their combustion heat efficiency and, compared to other fuels, glycine has a higher negative heat of combustion $(-3.24 \mathrm{kcal} / \mathrm{g})$ than urea $(-2.98 \mathrm{kcal} / \mathrm{g})$ and citric acid $(-2.76 \mathrm{kcal} / \mathrm{g}){ }^{26}$

The combustion reaction is based on different stoichiometric ratios. The grain size mainly depends upon its final adiabatic temperature during the combustion reaction. The grain size decreased from $55 \pm 5 \mathrm{~nm}$ to $16 \pm 5 \mathrm{~nm}$ when the fuel was reduced from rich to lean condition. The temperature and expansion of the lattice decreased the grain size as reported earlier. ${ }^{27-36}$ The lattice parameters were calculated using the following equations. ${ }^{37,38}$ The lattice parameter values are tabulated in Table 1.

To calculate the lattice constant:

$$
\mathrm{d}=\frac{\mathrm{a}}{\sqrt{\left(\mathrm{h}^{2}+\mathrm{k}^{2}+\mathrm{I}^{2}\right)}}
$$

where $\mathrm{d}$ is line spacing between planes which can be calculated by Bragg's equation:

$$
2 \mathrm{~d} \sin \theta=n \lambda
$$

and a is lattice constant; (hkl) is the indexing plane of atoms which can be obtained from X-ray diffraction data:

$$
\text { X- ray diffraction density } \rho_{\mathrm{X}}=\frac{8 \mathrm{M}}{N_{\mathrm{A}} \mathrm{a}^{3}}
$$

where $\mathrm{M}$ is molecular weight and $N_{\mathrm{A}}$ is Avogadro's number.

\section{FT-IR spectroscopy}

The functional groups of cobalt ferrite nanoparticles were identified by FT-IR spectroscopy. Figure 3 indicates the FT-IR spectrum of cobalt ferrite nanoparticles. The stretching and bending vibration of the two bands of metal oxide were observed in the range of $418 \pm 5 \mathrm{~cm}^{-1}$ and $575 \pm 5 \mathrm{~cm}^{-1}$. The presence of bands at $\sim 420 \mathrm{~cm}^{-1}$ and $\sim 580 \mathrm{~cm}^{-1}$ in FT-IR spectrum confirmed the formation of ferrite. The bending vibration was very broad. The reason could be attributed to the distribution of $\mathrm{Fe}^{3+}$ ions at tetrahedral sites. The difference in frequencies might be due to change in the bond length between $\mathrm{Fe}^{3+}$ and $\mathrm{O}^{2-}$, which are located at octahedral and tetrahedral sites. ${ }^{39-41}$

\section{Surface morphology and elemental analysis of $\mathrm{CoFe}_{2} \mathrm{O}_{4}$}

The SEM photographs of the cobalt ferrite magnetic nanoparticles are shown in Figures 4 and 5. The prepared cobalt ferrite magnetic nanoparticles were highly agglomerated with homogeneous distribution. Formation of agglomerated particles arose due to less gas being released during the combustion process, which occurred in the fuel lean condition. The surface of $\mathrm{CoFe}_{2} \mathrm{O}_{4}$ appeared like a "platelet" type of morphology, as shown in Figure 4. The fuel ratio played a major role in the adiabatic temperature changes as observed

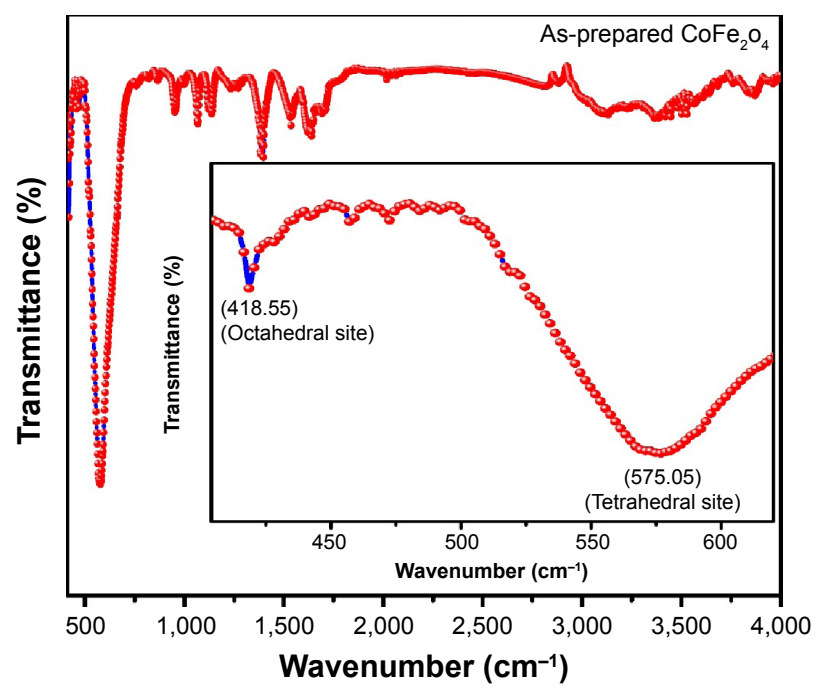

Figure 3 Fourier-transform infrared spectra of cobalt ferrite magnetic nanoparticles. 

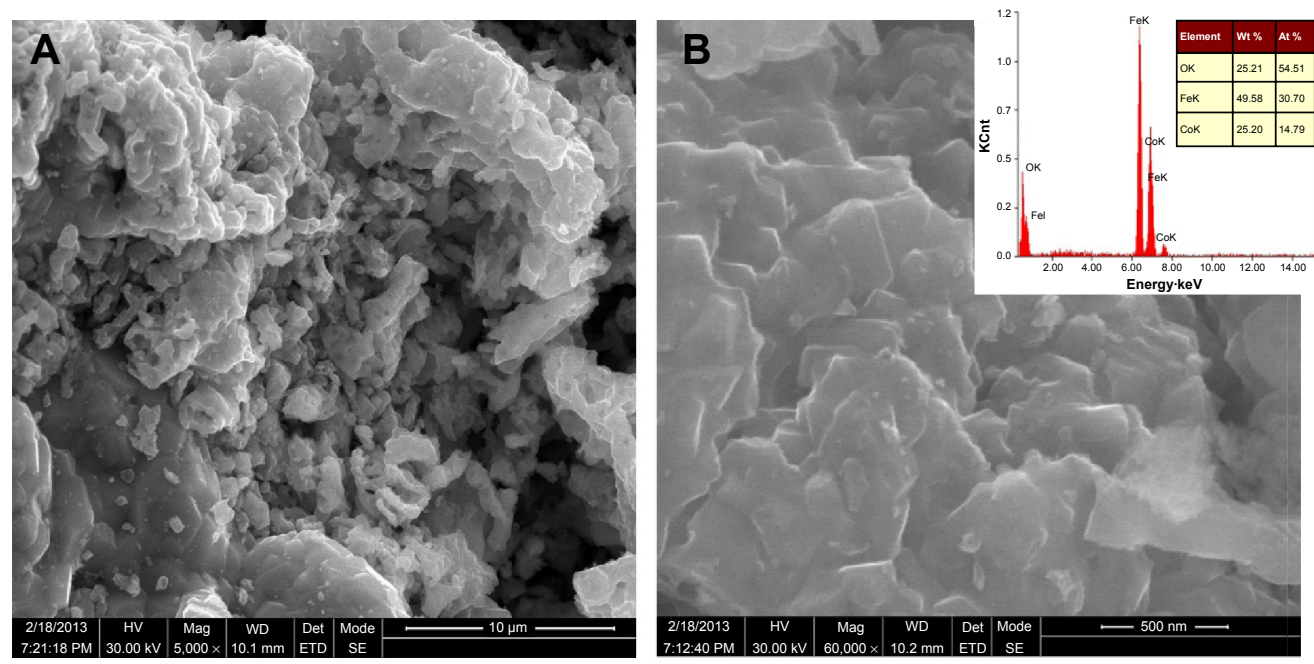

Figure 4 Scanning electron microscope image for fuel-lean-condition cobalt ferrite magnetic nanoparticles.

Notes: $\mathbf{A}$ and $\mathbf{B}$ are the surface morphology of $\mathrm{CoFe}_{2} \mathrm{O}_{4}$ with different magnification. Inset: X-ray spectroscopy analysis of CoFe $\mathrm{O}_{4}$.

in the microstructure, porosity, and the random distribution of particles. Higher final adiabatic temperature was attained from a fuel rich condition leading to a larger amount of gas released. This results in a highly porous nature (Figure 5), which agrees with the results of Chick et $\mathrm{al}^{42}$ and Mimani. ${ }^{43}$ The particles were of irregular shapes and different sizes, and the agglomeration of the particles occurred due to the combustion reaction.

Using the EDX analysis, the compositions of elements present in the sample were measured and the Atomic\% of $\mathrm{Co}, \mathrm{Fe}$, and $\mathrm{O}$ was found to be $14.79,30.70$, and 54.51 ,

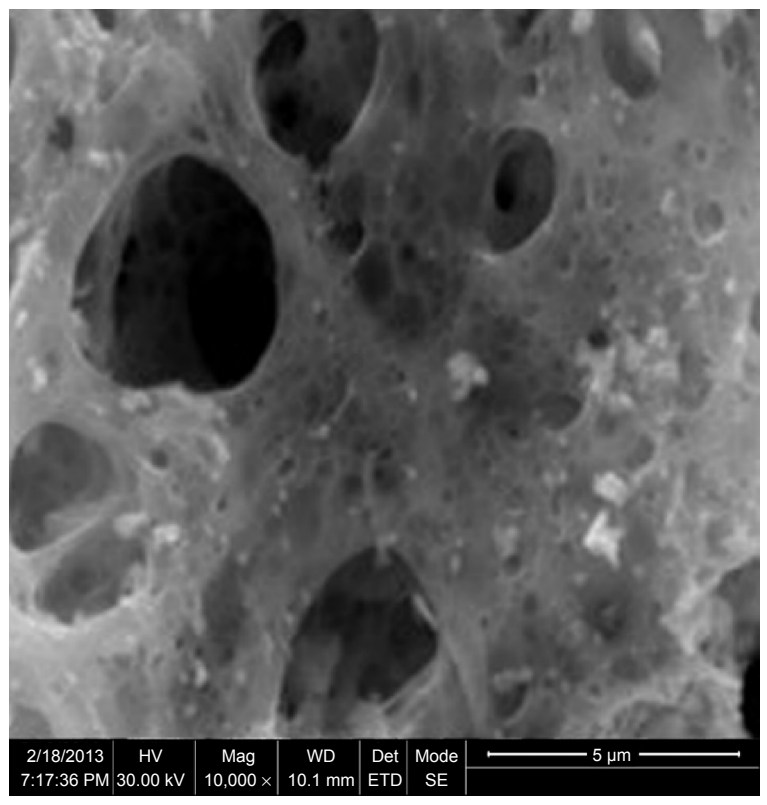

Figure 5 Scanning electron microscope image for fuel-rich-condition cobalt ferrite magnetic nanoparticles. respectively. The exact stoichiometry of $\mathrm{CoFe}_{2} \mathrm{O}_{4}(1: 2: 4)$ was also confirmed by this measurement. The spectrum of EDX is given in the inset of Figure 4.

\section{HR-TEM of $\mathrm{CoFe}_{2} \mathrm{O}_{4}$}

The HR-TEM images of cobalt ferrite magnetic nanoparticles are shown in Figure 6. From the image, the average particle size was measured as $16 \pm 5 \mathrm{~nm}$, which is comparable with the value calculated by the Scherrer equation applied to the X-ray diffraction pattern. The HR-TEM image also indicates the crystalline nature of the sample which reveals the appearance of clear lattice fringes of cobalt ferrite crystalline particle. The atomic arrangements in the lattice fringes show the defect-free lattice structure of $\mathrm{CoFe}_{2} \mathrm{O}_{4}$ (Figure 6). A few particles emerged in spherical shape. However, some elongated particles were also present, as shown in the TEM images. Some moderately agglomerated particles as well as separated particles were seen in the images. The particles were distributed randomly due to temperature effect. ${ }^{44}$

\section{Magnetic properties of $\mathrm{CoFe}_{2} \mathrm{O}_{4}$ using VSM}

The magnetic properties of $\mathrm{CoFe}_{2} \mathrm{O}_{4}$ were measured at room temperature using VSM. The M-H measurement exhibits a clear hysteresis loop. This proves that the cobalt ferrite magnetic nanoparticles were of ferromagnetic nature. The magnetic properties, such as saturation magnetization $\left(\mathrm{M}_{\mathrm{s}}\right)$, coercivity $\left(\mathrm{H}_{\mathrm{c}}\right)$, and remanence magnetization were measured as $47 \mathrm{emu} / \mathrm{g}, 947 \mathrm{Oe}$, and $14.44 \mathrm{emu} / \mathrm{g}$, respectively, for the sample prepared at fuel lean condition. 

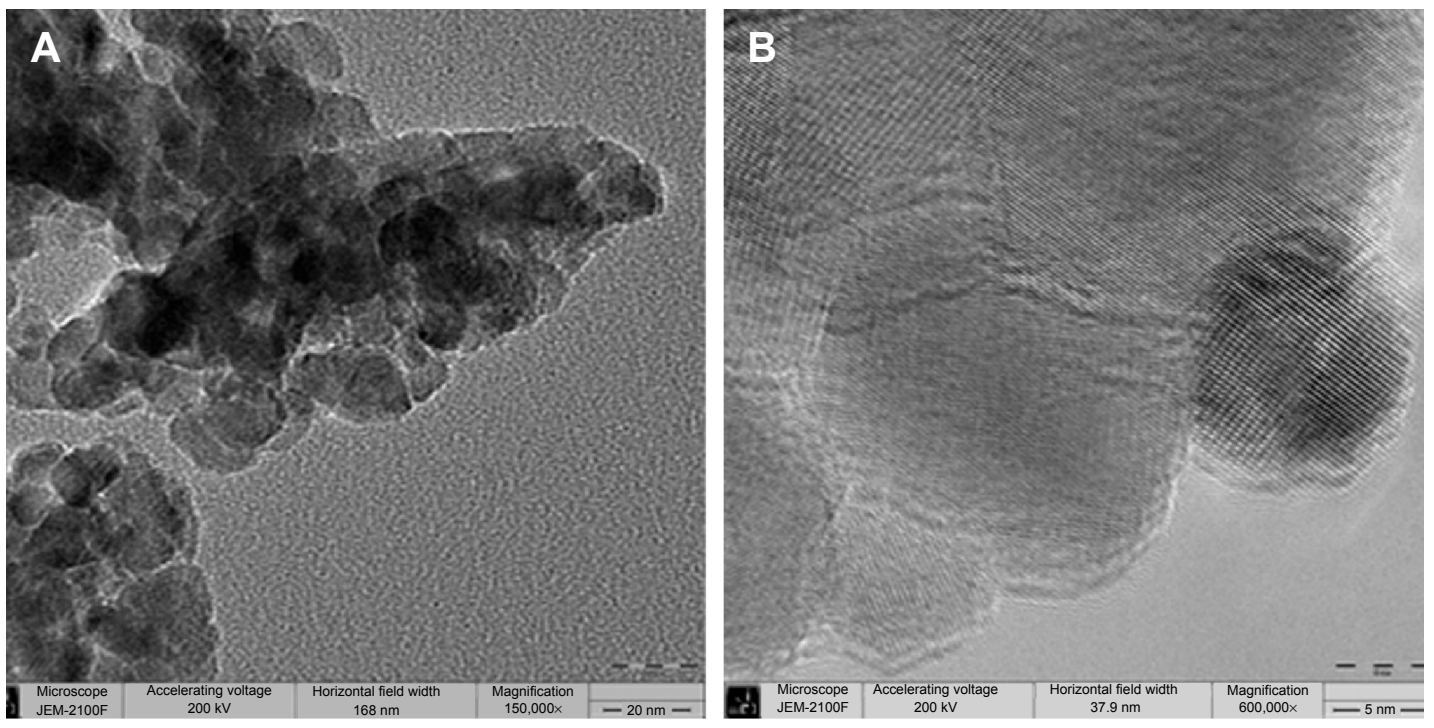

Figure 6 High-resolution transmission electron microscope image of cobalt ferrite magnetic nanoparticles.

Notes: $\mathbf{A}$ indicates the measurement of the size of $\mathrm{CoFe}_{2} \mathrm{O}_{4}$ nanoparticle. $\mathbf{B}$ shows the spherical shape and the arrangement of the lattice fringes.

The saturation magnetization was verified by the law of approach to saturation method. ${ }^{45}$ The law of approach to saturation depicted the magnetization of $\mathrm{M}$ dependence upon the applied magnetic field for $\mathrm{H}>\mathrm{H}_{\mathrm{c}}$. Using this method, the magnetocrystalline anisotropy $\left(\mathrm{K}_{1}\right)$ was calculated as $0.7 \times 10^{6}$, and the magnetization can be written as:

$$
\begin{aligned}
& \mathrm{M}=\mathrm{M}_{\mathrm{s}}\left[1-\frac{\mathrm{b}}{\mathrm{H}^{2}}\right] \\
& \mathrm{b}=\frac{8}{105} \times \frac{\mathrm{K}_{1}^{2}}{\mu_{0}^{2} \mathrm{M}_{\mathrm{S}}^{2}}
\end{aligned}
$$

where $\mathrm{M}$ is the magnetization, $\mathrm{H}$ is applied magnetic field, $K_{1}$ is the magnetocrystalline anisotropy constant, $\mu_{0}$ is the permeability of free space, and $\mathrm{M}_{\mathrm{s}}$ is the saturation magnetization.

The $\mathrm{K}_{1}$ was calculated by the equation: ${ }^{46}$

$$
\mathrm{K}_{1}=\mu_{\mathrm{o}} \mathrm{Ms} \sqrt{\frac{105 \mathrm{~b}}{8}}
$$

The laws of approach to saturation curve fit was similar to the experimental curve (Figure 7).

\section{Antibacterial activity against $\mathrm{CoFe}_{2} \mathrm{O}_{4}$}

In the present study, the nanosized particles were employed to kill the bacteria. The antibacterial activity was carried out with proper replicates (Table 2). The well diffusion method served as an efficient method for evaluating antibacterial activity over the paper disc method. In the case of well diffusion method, the particles are dispersed in the solvent. Here, the nanoparticles could easily diffuse through the agar media and also produced inhibitory an effect over the bacteria. But in case of classical method, namely the paper disc method, the paper discs are immersed in the dispersed solvent and the discs are placed over the bacterial culture. The disadvantage of the paper disc method is that the nanoparticles may not attach to the disc and inhibition may not be possible at this level. Hence, the well diffusion method is the preferred method to study the antibacterial activity. Cobalt ferrite nanoparticles showed better results as an antibacterial agent. The antibacterial effect of the nanoparticles might be due to several possible mechanisms.

The antibacterial activity of cobalt ferrite magnetic nanoparticles over the bacterial cells was influenced mainly by the cell wall structure as in E. coli, where the cell wall consisted of lipid A, lipopolysaccharides, and peptidoglycan, whereas other bacterial cells may not possess the same structure. ${ }^{47,48}$ Thus, the activity varied among the bacterial community. The single phase of the cobalt ferrite magnetic nanoparticles also played an important role in antibacterial activity. The field-emission SEM images showed the cell wall disruption for groups of bacterial cells (Figures 8 and 9) and it also showed that the cell wall disruption occurred on individual cells during cell division.

$\mathrm{CoFe}_{2} \mathrm{O}_{4}$ magnetic nanoparticles showed inhibition at a concentration of $50 \mathrm{mg} / \mathrm{L}$ against $E$. coli (Figure 10). The single phase of the cobalt ferrite magnetic nanoparticles and the generated hydrogen peroxide penetrated into the 


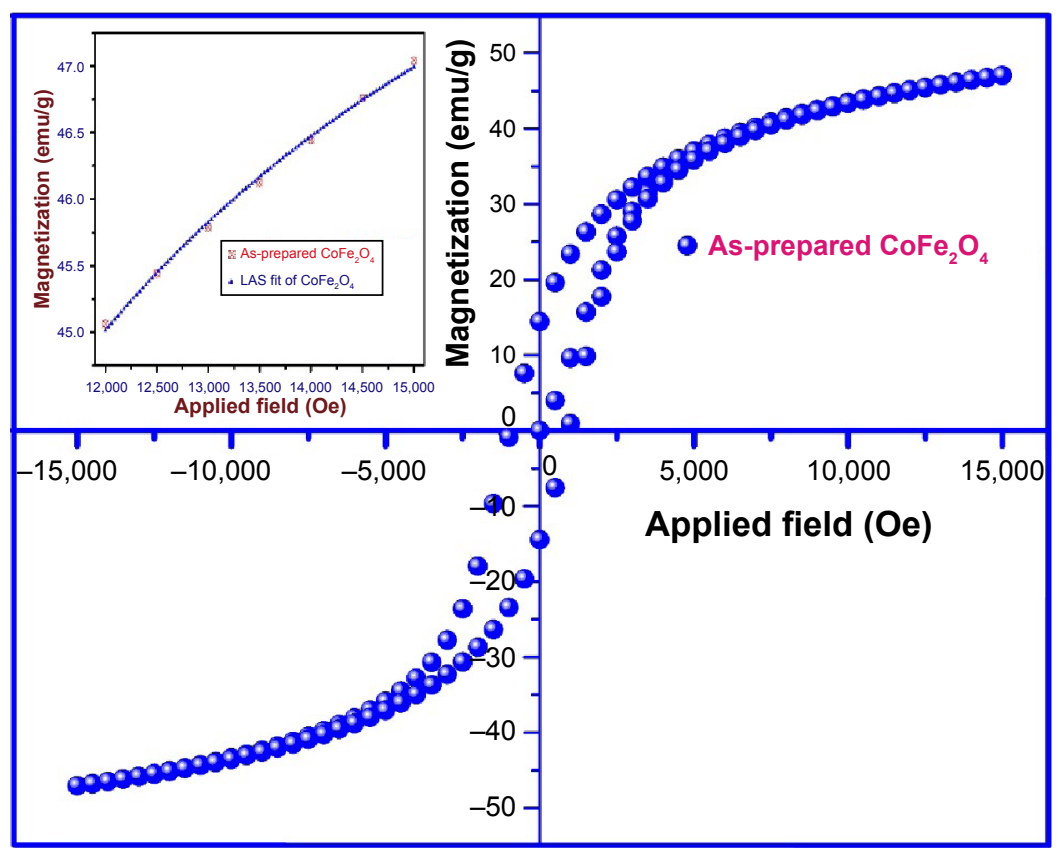

Figure 7 Hysteresis loop of cobalt ferrite magnetic nanoparticles. Abbreviation: LAS, laws of approach to saturation.

cell wall and caused cell death. ${ }^{49}$ The rate of penetration of this hydrogen peroxide also played an important role in antibacterial activity.

\section{Estimation of affinity constant}

Studies on bacterial growth inhibition were taken up using nanoparticles to determine the affinity constant $\left(\mathrm{K}_{\text {aff }}\right)$. Concentrations of nanoparticles were taken in different test tubes in such a way that the concentration ranged from 50 to $2,000 \mathrm{mg} / \mathrm{L} \mathrm{v} / \mathrm{v}$. To this was added $500 \mu \mathrm{L}$ of inoculum, which was prepared from overnight growth of the test organism, so as to match the turbidity of $0.5 \mathrm{McF}$ arland standard.

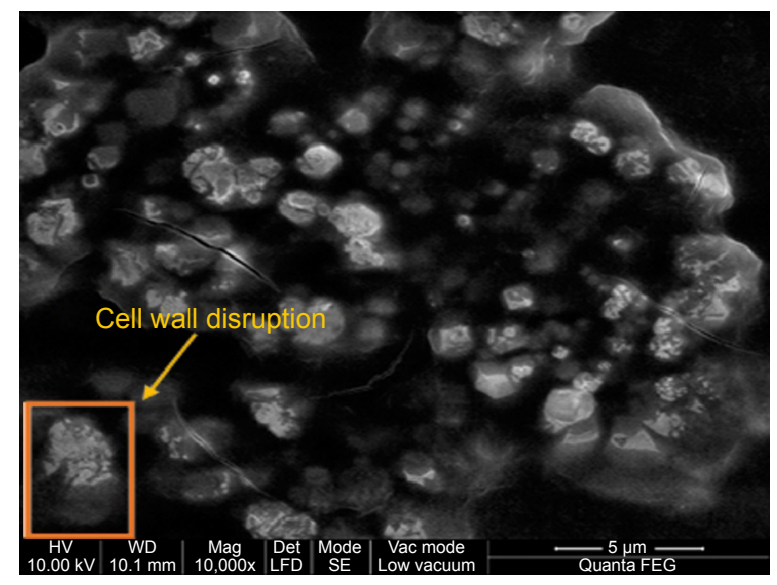

Figure 8 Field-emission scanning electron microscopy of cobalt ferrite magnetic nanoparticles interacting with cell wall, and the disruption of the cell wall.
Total volume in each of the tubes was thus made to $2 \mathrm{~mL}$. A tube containing growth medium $(1,500 \mu \mathrm{L})$ was inoculated with $50 \mu \mathrm{L}$ of inoculum, and labeled as growth control. Tubes containing different concentration of nanoparticles ranging from 50 to $2,000 \mathrm{mg} / \mathrm{L}$ were used as test samples. An inoculated tube of Müller Hinton broth $(2 \mathrm{~mL})$ was labeled as control. Incubation was at $35^{\circ} \mathrm{C}$ for $0-16$ hours, and optical density was measured at $625 \mathrm{~nm}$ (ELICO SL160 double beam UV-Vis spectrophotometer). Growth in each of the "test" tubes was expressed relative to that of "control".

The percentage of growth inhibition curve was plotted as test/control $\times 100$.

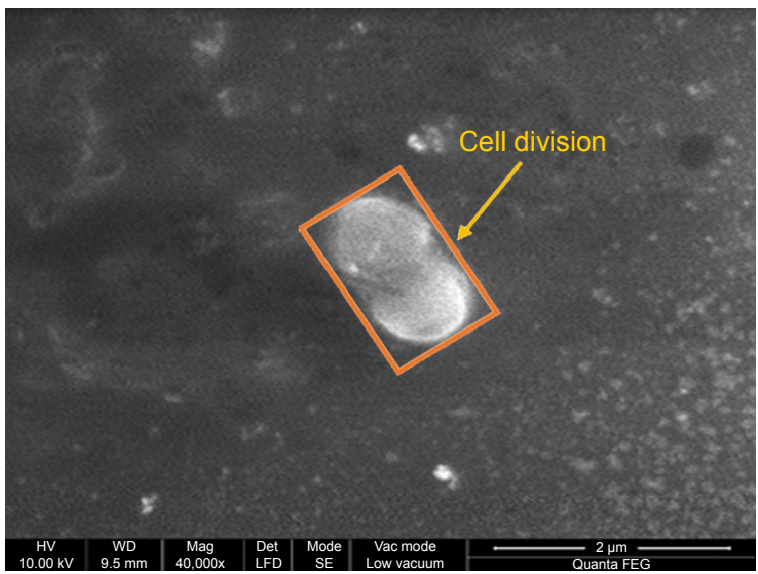

Figure 9 Field-emission scanning electron microscopy of cell division and its disruption. 


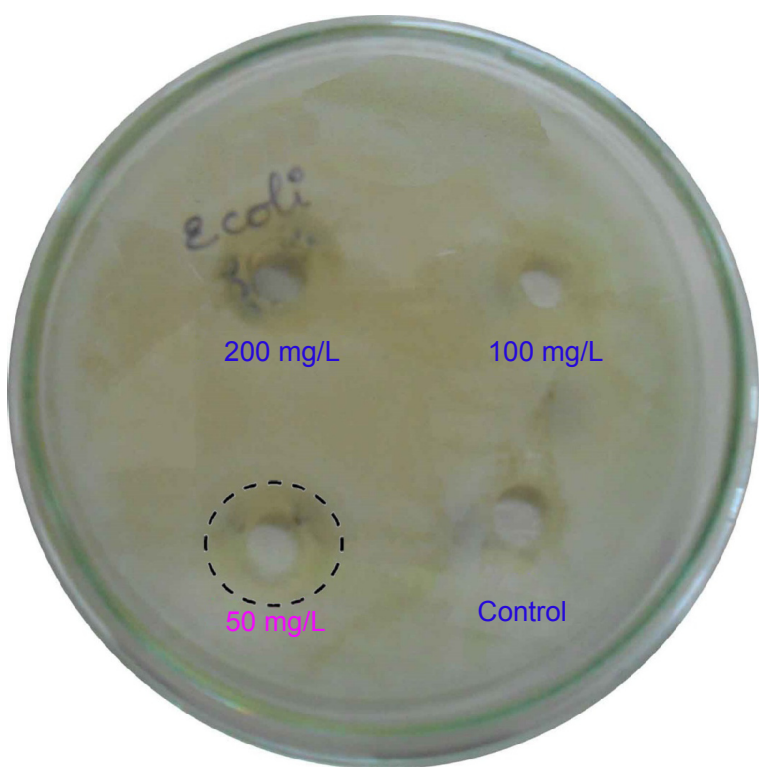

Figure 10 Antibacterial activity on cobalt ferrite magnetic nanoparticles.

The growth inhibition in colony forming units (CFU) was calculated as test optical density (OD)/control OD; control OD resembles the growth of $1 \times 10^{8} \mathrm{CFU} / \mathrm{mL}$.

The $\mathrm{K}_{\text {aff }}$ was measured as $0.05 .{ }^{50}$ The $\mathrm{K}_{\text {aff }}$ was determined by fitting a graphical representation of inhibition percentage from the growth versus nanoparticle concentrations with the hyperbolic function of nonlinear regression:

$$
y=\frac{a x}{b+x}
$$

Using equation (9) and Figure $11 \mathrm{~K}_{\text {aff }}$ value was calculated as $0.05 .^{50}$

\section{Cytotoxicity assay}

The toxicity of the cobalt ferrite nanoparticle was reported for normal cells by Surendra et al. ${ }^{51}$ The cytotoxicity test for

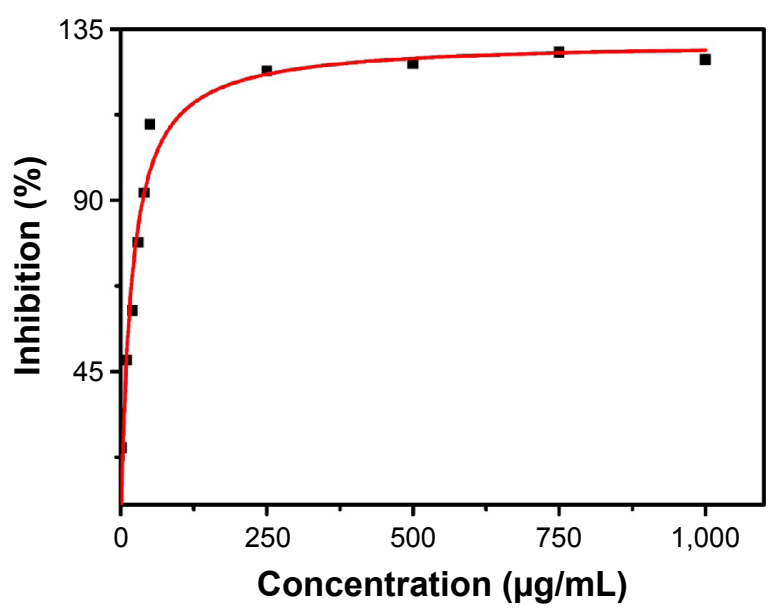

Figure I I Hyperbolic function fitting with inhibitory effect.
MTT assay

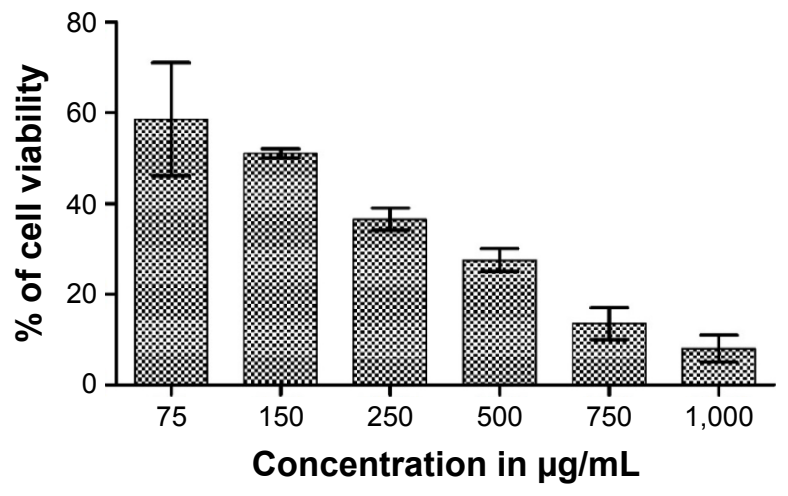

Figure 12 MTT assay of cobalt ferrite magnetic nanoparticles.

Abbreviation: MTT, 3-(4,5-dimethylthiazol-2-yl)-2,5-diphenyltetrazolium bromide.

cell viability was evaluated for cobalt ferrite particles against MCF-7 breast cancer cell lines. The cytotoxicity assay relies on the mitochondrial activity of mammalian cell lines and represents a parameter for their metabolically active cells. In this study, the viability of MCF-7 is measured by cytotoxicity assay after incubating nanoparticles along with the cells for 24 hours. The MCF-7 cell lines after contact with 75, 150, 250, 500, 750, and $1,000 \mu \mathrm{g} / \mathrm{mL}$ of nanoparticles showed $55 \%, 51 \%, 36 \%$, $27 \%, 14 \%$, and $7 \%$, respectively. The control (untreated) cell lines showed 100\% metabolic activity (Figure 12, Table 3).

In this in vitro anticancer study, it is evident that the cytotoxicity of nanoparticles depends on the concentration effect against the cell lines. ${ }^{52}$ The $50 \%$ inhibitory concentration value was observed at a concentration of $150 \mu \mathrm{g} / \mathrm{mL}$. The lowest concentration of cytotoxicity results against the MCF-7 cell lines using the cobalt ferrite nanoparticles is being reported for first time. Even though nanoparticles served as a potential anticancer agent, their toxicity toward cancer cells is not heavily researched. The cobalt ferrite nanoparticles on these criteria of anticancer scope is still in dry pipeline. These findings might facilitate the secondary level of anticancer agents from inorganic particles, especially cobalt ferrite nanoparticles.

\section{Conclusion}

The single phase of $\mathrm{CoFe}_{2} \mathrm{O}_{4}$ was confirmed by powder X-ray diffraction, and the average crystallite size of $16 \pm 5 \mathrm{~nm}$ was

Table 2 Antibacterial inhibition assay

\begin{tabular}{ll}
\hline Concentration (mg/L) & Inhibition zone (in $\mathbf{~ m m})$ \\
\hline 50 & 3.8 \\
250 & 4.01 \\
500 & 4.53 \\
750 & 6.28 \\
1,000 & 6.46 \\
2,000 & 7.31 \\
\hline
\end{tabular}

Notes: $F$-test: no significant difference $(P<0.05)$. The values are the average of triplicates. 
Table 3 Cytotoxicity assay

\begin{tabular}{|c|c|c|c|c|c|}
\hline \multicolumn{6}{|c|}{ Concentration of $\mathrm{CoFe}_{2} \mathrm{O}_{4}$} \\
\hline 75 & 150 & 250 & 500 & 750 & 1,000 \\
\hline$\mu g / \mathrm{mL}$ & $\mu \mathrm{g} / \mathrm{mL}$ & $\mu g / \mathrm{mL}$ & $\mu g / m L$ & $\mu g / m L$ & $\mu g / \mathrm{mL}$ \\
\hline \multicolumn{6}{|c|}{ Metabolic activity of cancer cell lines } \\
\hline $55 \%$ & $51 \%$ & $36 \%$ & $27 \%$ & $14 \%$ & $7 \%$ \\
\hline
\end{tabular}

Notes: $F$-test: no significant difference $(P<0.05)$. The values are the average of triplicates.

calculated by Scherrer equation. The SEM image shows that the particles were highly agglomerated with plate type morphology. Using TEM imaging, the particle size of $16 \pm 5 \mathrm{~nm}$ was determined, and it was found to be equal to the value that was calculated by the Scherrer equation. The HR-TEM image confirmed the crystalline nature of cobalt ferrite nanoparticles. The $\mathrm{M}-\mathrm{H}$ curve shows the $M_{\mathrm{s}}$ of the cobalt ferrite nanoparticles as $47 \mathrm{emu} / \mathrm{g}$ at room temperature. The antibacterial activity against $E$. coli showed a zone width of $3 \mathrm{~mm}$ at the concentration of $50 \mathrm{mg} / \mathrm{L}$. Based on the above studies, it could be concluded that the cobalt ferrite nanoparticle has potential for biological applications, but further studies need to be taken up for clinical applications.

\section{Acknowledgments}

Authors are thankful to the management of VIT University, Vellore, Tamil Nadu, India, for their continuous support and encouragement. KV is extremely thankful to the VIT management for providing Research Associateship and extends his heartfelt thanks to SRM University (Kattankulathur), Karunya University (Coimbatore), and IIT-SAIF (Chennai), for providing field-emission SEM, SEM, and VSM characterizations.

\section{Disclosure}

The authors report no conflicts of interest in this work.

\section{References}

1. Chavan SM, Babrekar MK, More SS, Jadhav KM. Structural and optical properties of nanocrystalline $\mathrm{Ni}-\mathrm{Zn}$ ferrite thin films. $J$ Alloys Compd. 2010;507(1):21-25.

2. Berger Patricia, Adelman NB, Beckman KJ, Campbell DJ, Ellis AB, Lisensky GC. Preparation and properties of an aqueous ferrofluid. J Chem Educ. 1999;76(7):943-948.

3. Bian P, McCarthy TJ. Polymerization of monomer-based ferrofluids. Langmuir. 2010;26(9):6145-6148.

4. Licciardi M, Scialabba C, Fiorica C, Cavallaro G, Cassata G, Giammona G. Polymeric nanocarriers for magnetic targeted drug delivery: preparation, characterization, and in vitro and in vivo evaluation. Mol Pharm. 2013;10:4397-4407.

5. Wang Y, Li B, Zhang L, Song H, Zhang L. Targeted delivery system based on magnetic mesoporous silica nanocomposites with light-controlled release character. ACS Appl Mater Interfaces. 2013;5:11-15.

6. Ningning W, O’Donnell T, Roy S, McCloskey P, O’Mathuna C. Microinductors integrated on silicon for power supply on chip. J Magn Magn Mater. 2007;316:e233-e237.
7. Choi KH, Wang KK, Shin EP, et al. Water-soluble magnetic nanoparticles functionalized with photosensitizer for photocatalytic application. J Phys Chem C. 2011;115:3212-3219.

8. Chalasani R, Vasudevan S. Cyclodextrin-functionalized $\mathrm{Fe}_{3} \mathrm{O}_{4} @ \mathrm{TiO}_{2}$ : reusable, magnetic nanoparticles for photocatalytic degradation of endocrine-disrupting chemicals in water supplies. ACS Nano. 2013; 7(5):4093-4104.

9. Darshane SL. Suryavanshi SS, Mulla IS. Nanostructured nickel ferrite: A liquid petroleum gas sensor. Ceram Int. 2009;35:1793-1797.

10. Arshak K, Gaidan I. Development of a novel gas sensor based on oxide thick films. Mater Sci Eng B Solid State Mater Adv Technol. 2005;118: 44-49.

11. Liu YL, Liu ZM, Yang Y, Yang HF, Shen GL, Yu RQ. Simple synthesis of $\mathrm{MgFe}_{2} \mathrm{O}_{4}$ nanoparticles as gas sensing materials. Sens Actuators B Chem. 2005;107(2):600-604.

12. Yootarou Y, Satou M. High frequency conductivity in cobalt-iron ferrite. Jpn J Appl Phys. 1973;12(7):998.

13. Aldar BA, Pinjari RK, Burange NM. Electric and dielectric behavior of Ni-Co-Cd Ferrite. J Appl Phys. 2014;6(4 Ver II):23-26.

14. Franco A Jr, Zapf V. Temperature dependence of magnetic anisotropy in nanoparticles of $\mathrm{Co}_{\mathrm{x}} \mathrm{Fe}_{(3-x)} \mathrm{O}_{4} . J$ Magn Magn Mater. 2008;320: 709-713.

15. Sutka A, Mezinskis G. Sol-gel auto-combustion synthesis of spinel-type ferrite nanomaterials. Front Mater Sci. 2012;6(2):128-141.

16. Gul IH, Ahmed W, Maqsood A. Electrical and magnetic characterization of nanocrystalline $\mathrm{Ni}-\mathrm{Zn}$ ferrite synthesis by co-precipitation route. J Magn Magn Mater. 2008;320(3-4):270-275.

17. Košak A, Makovec D, Žnidaršič A, Drofenik M. Preparation of MnZn-ferrite with microemulsion technique. J Eur Ceram Soc. 2004; 24(6):959-962.

18. Takayama A, Okuya M, Kaneko S. Spray pyrolysis deposition of NiZn ferrite thin films. Solid State Ionics. 2004;172(1-4):257-260.

19. Jiao $\mathrm{X}$, Chen $\mathrm{D}, \mathrm{Hu} \mathrm{Y}$. Hydrothermal synthesis of nanocrystalline $\mathrm{M}_{\mathrm{x}} \mathrm{Zn}_{1-\mathrm{x}} \mathrm{Fe}_{2} \mathrm{O}_{4}(\mathrm{M}=\mathrm{Ni}, \mathrm{Mn}, \mathrm{Co} ; x=0.40-0.60)$ powders. Mater Res Bull. 2002;37(9):1583-1588.

20. Sarangi PP, Vadera SR, Patra MK, Ghosh NN. Synthesis and characterization of pure single phase $\mathrm{Ni}-\mathrm{Zn}$ ferrite nanopowders by oxalate based precursor method. Powder Technol. 2010;203(2):348-353.

21. Zahi S, Hashim M, Daud AR. Synthesis, magnetic properties and microstructure of Ni-Zn ferrite by sol-gel technique. J Magn Magn Mater. 2007;308(2):177-182.

22. Aruna ST, Mukasyan AS. Combustion synthesis and nanomaterials. Curr Opin Solid State Mater Sci. 2008;12(3-4):44-50.

23. Vidya R, Venkatesan K. Preparation and characterization of zinc ferrite $\left(\mathrm{ZnFe}_{2} \mathrm{O}_{4}\right)$ nanoparticles using self-propagated combustion route and evaluation of antimicrobial activity. Res J Pharm Biol Chem Sci. 2015;6(1):537-542.

24. Zhao L, Zhang H, Xing Y, et al. Studies on the magnetism of cobalt ferrite nanocrystals synthesized by hydrothermal method. J Solid State Chem. 2008;181:245-252.

25. Patil KC, Hegde MS, Rattan T, Aruna ST. Chemistry of nanocrystalline oxide materials - Combustion synthesis, properties and applications. Hackensack: World Scientific Publishing Co. Pte. Ltd; 2008.

26. Salunkhe AB, Khot VM, Phadatare MR, Pawar SH. Combustion synthesis of cobalt ferrite nanoparticles-Influence of fuel to oxidizer ratio. J Alloys Compd. 2012;514:91-96.

27. Srivastav AK, Chawake N, Murty BS. Grain-size-dependent nonmonotonic lattice parameter variation in nanocrystalline $\mathrm{W}$ : The role of non-equilibrium grain boundary structure. Scr Mater. 2015;98: 20-23.

28. Datta MK, Pabi SK, Murty BS. Face-centered-cubic to Hexagonalclose-packed Transformation in Nanocrystalline Ni(Si) by Mechanical Alloying. J Mater Res. 2000;15:1429-1432.

29. Sheng J, Welzel U, Mittemeijer EJ. Nonmonotonic crystallite-size dependence of the lattice parameter of nanocrystalline nickel. Appl Phys Lett. 2010;97:153109.

30. Rane GK. Microstructure and grain growth of nanosized materials [PhD thesis]. Stuttgart: University of Stuttgart; 2012. 
31. Diehm PM, Ágoston P, Albe K. Size-dependent lattice expansion in nanoparticles: reality or anomaly? Chemphyschem. 2012;13(10): 2443-2454.

32. Gamarnik MY. Change of Lattice Parameters in Highly Disperse Nickel Powders. Phys Status Solidi B Basic Solid State Phys. 1991;168: 389-395.

33. Vermaak JS, Mays CW, Kuhlmann-Wilsdorf D. On surface stress and surface tension. I. Theoretical considerations. Surf Sci. 1968;12(2): $128-133$.

34. Lu K, Sun NX. Grain-boundary enthalpy of nanocrystalline selenium. Philos Mag Lett. 1997;75:389-395.

35. Qin W, Chen ZH, Huang PY, Zhuang YH. Crystal lattice expansion of nanocrystalline materials. J Alloys Compd. 1999;292:230-232.

36. Liu XD, Zhang HY, Lu K, Hu ZQ. The lattice expansion in nanometresized Ni polycrystals. J Phys Condens Matter. 1994;6:L497.

37. Cullity BD. Elements of X-ray Diffraction. Addison-Wesley Publication Company Inc., Reading UK. 1956.

38. Shinde TJ, Gadkari AB, Vasambekar PN. DC resistivity of Ni-Zn ferrite prepared by oxalate precipitation method. Mater Chem Phys. 2008; 111:87-91.

39. Waldron RD. Infrared spectra of ferrites. Physics Review. 1955;99: 1727.

40. Khandekar MS, Kambale RC, Patil JY, Kolekar YD, Suryavanshi SS. Effect of calcination temperature on the structural and electrical properties of cobalt ferrite synthesized by combustion method. J Alloys Compd. 2011;509:1861-1865.

41. West AR. Solid State Chemistry and its Applications. John Wiley \& Sons (Asia) Pte. Ltd., 2003.

42. Chick LA, Pederson LR, Maupin GD, Bates JL, Thomas LE, Exarhos GJ. Glycine-nitrate combustion synthesis of oxide ceramic powders. Mater Lett. 1990;10(1-2):6-12.
43. Mimani T. Instant synthesis of nanoscale spinel aluminates. J Alloys Compd. 2001;315:123-128.

44. Maaz K, Mumtaz A, Hasanain SK, Ceylan A. Synthesis and magnetic properties of cobalt ferrite $\left(\mathrm{CoFe}_{2} \mathrm{O}_{4}\right)$ nanoparticles prepared by wet chemical route. J Magn Magn Mater. 2007;308(2):289-295.

45. Chikazumi Sozhin. Physics of Ferromagnetism. 2nd ed. New York: Oxford University Press; 1997.

46. Kumar L, Kar M. Effect of $\mathrm{Ho}^{3+}$ substitution on the cation distribution, crystal structure and magnetocrystalline anisotropy of nanocrystalline cobalt ferrite. J Exp Nanosci. 2014;9(4):362-374.

47. Zhang L, Pornpattananangkul D, Hu CM, Huang CM. Development of nanoparticles for antimicrobial drug delivery. Curr Med Chem. 2010; $17: 585-594$

48. Sanpo N, Wang J, Berndt CC. Influence of Chelating Agents on the Microstructure and Antibacterial Property of Cobalt Ferrite Nanopowders. Journal of the Australian Ceramic Society. 2013;49(1):84-91.

49. Sumathi S, Nehru M, Vidya R. Synthesis, characterization and effect of precipitating agent on the antibacterial properties of cobalt ferrite nanoparticles. Transactions of the Indian Ceramic Society. 2015; 73(2):1-4.

50. Giordani R, Buc J, Regli P. Mathematical modelling of antifungal action. Mycoses. 2002;45:482-487.

51. Surendra MK, Dutta R, Rao MSR. Realization of highest specific absorption rate near superparamagnetic limit of $\mathrm{CoFe}_{2} \mathrm{O}_{4}$ colloids for magnetic hyperthermia applications. Materials Research Express. 2014; 1:026107.

52. Al-Qubaisi MS, Rasedee A, Flaifel MH. Cytotoxicity of nickel zinc ferrite nanoparticles on cancer cells of epithelial origin. Int J Nanomedicine. 2013;8:2497-2508.
International Journal of Nanomedicine

\section{Publish your work in this journal}

The International Journal of Nanomedicine is an international, peerreviewed journal focusing on the application of nanotechnology in diagnostics, therapeutics, and drug delivery systems throughout the biomedical field. This journal is indexed on PubMed Central, MedLine, CAS, SciSearch ${ }^{\circledR}$, Current Contents ${ }^{\circledR} /$ Clinical Medicine,

\section{Dovepress}

Journal Citation Reports/Science Edition, EMBase, Scopus and the Elsevier Bibliographic databases. The manuscript management system is completely online and includes a very quick and fair peer-review system, which is all easy to use. Visit http://www.dovepress.com/ testimonials.php to read real quotes from published authors. 